\title{
Unusual Pyrrolyl 4-Quinolinone Alkaloids from the Marine-Derived Fungus Penicillium sp. ghq208
}

\author{
Huquan Gao, Lianqing Zhang, Tianjiao Zhu, Qianqun Gu, and Dehai Li* \\ Key Laboratory of Marine Drugs, Chinese Ministry of Education, School of Medicine and Pharmacy, Ocean \\ University of China; Qingdao 266003, P. R. China. \\ Received May 29, 2012; accepted August 15, 2012; advance publication released online September 4, 2012
}

One new pyrrolyl 4-quinolinone alkaloid, penicinoline $\mathbf{E}$ (1), together with three known deriverites, methyl-penicinoline (2), penicinoline (3), and quinolactacide (4), were isolated from the marine-derived fungus Penicillium sp. ghq208. The structures of these isolated compounds were elucidated by spectroscopic methods. Compounds $(2,3)$ exhibited moderate cytotoxicities against the HepG2 cell line with $\mathrm{IC}_{50}$ values of 11.3 and $13.2 \mu \mathrm{M}$, respectively.

Key words Penicillium; marine-derived fungus; alkaloid; penicinoline

Alkaloids are a large group of secondary metabolites which produced by many organisms, which contain almost $40 \%$ metabolites of microorganisms. ${ }^{1)}$ These N-containing metabolites usually biosynthesis by a convergence of multiple biosynthetic pathways from many kinds of amino acids, ${ }^{2}$ and they have the novelty and diversity of structures. In particular, they have a variety of biological activities such as antitumor, antipredator, antiinflammatory, and antiviral etc. Therefore, investigation of structurally novel and biologically active alkaloids from marine-derived microorganisms has been an important research area in new drug discovery. As part of our programs to search for bioactive secondary metabolites from marinederived microorganisms, ${ }^{3-5)}$ a fungal strain ghq208, identified as Penicillium sp., isolated from the sediment collected in Jiaozhou Bay of China, was found to produce alkaloids by TLC visualizing with Dragendorff's reagent in a saline culture. The EtOAc extract showed significant cytotoxicity on P388 cell line. Chemical investigation on the extract led to the isolation of one new and unusual pyrrolyl 4-quinolinone alkaloid, named penicinoline E (1), along with three known derivates, methyl-penicinoline (2), ${ }^{6}$ penicinoline (3), ${ }^{7}$ and quinolactacide (4) ${ }^{8)}$ (Fig. 1). In this paper, we describe the isolation, structural elucidation, and biological activities of these N-containing compounds.

\section{Results and Discussion}

Compound 1 was separated as a pale yellow powder, and its molecular formula was determined as $\mathrm{C}_{13} \mathrm{H}_{10} \mathrm{~N}_{2} \mathrm{O}$ on the basis of its high resolution-electrospray ionization-mass spectra (HR-ESI-MS) peak at $m / z 211.0863[\mathrm{M}+\mathrm{H}]^{+}$(Calcd for $\mathrm{C}_{13} \mathrm{H}_{11} \mathrm{~N}_{2} \mathrm{O}$ : 211.0866), indicating 10 degrees of unsaturation.
${ }^{1} \mathrm{H}$ - and ${ }^{13} \mathrm{C}-\mathrm{NMR}$ data of $\mathbf{1}$ showed eight aromatic methines, one conjugated carbonyl group and four quaternary carbons (Table 1), which were very similar to those of penicinoline (3), ${ }^{7}$ except for the difference of the absence of carboxyl group at $\mathrm{C}-3$. In the ${ }^{1} \mathrm{H}-\mathrm{NMR}$ spectrum, the chemical shifts and the coupling constants of $\mathrm{H}-5\left(\delta_{\mathrm{H}} 8.04, \mathrm{dd}, J=7.7,1.1 \mathrm{~Hz}\right)$, H-6 $\left(\delta_{\mathrm{H}} 7.27\right.$, ddd, $\left.J=7.7,7.7,1.1 \mathrm{~Hz}\right), \mathrm{H}-7\left(\delta_{\mathrm{H}} 7.61\right.$, ddd, $J=7.7$, $7.7,1.1 \mathrm{~Hz})$, and $\mathrm{H}-8\left(\delta_{\mathrm{H}} 7.72, \mathrm{dd}, J=7.7,1.1 \mathrm{~Hz}\right)$ indicated the presence of an ortho-disubstituted benzene system, which also supported by the ${ }^{1} \mathrm{H}-{ }^{1} \mathrm{H}$ correlation spectroscopy (COSY) correlations (Fig. 2). The quinolinone moiety was deduced by heteronuclear multiple bond connectivity (HMBC) correlations from $\mathrm{H}-3$ to $\mathrm{C}-2$ and $\mathrm{C}-4$, and from $\mathrm{H}-5$ to $\mathrm{C}-4$. The pyrrole ring was determined by comparison of the chemical shifts $\left(\delta_{\mathrm{H}} 11.33, \delta_{\mathrm{C}} 125.3, \delta_{\mathrm{C} / \mathrm{H}} 123.5 / 7.08,111.0 / 7.05\right.$ and $\left.110.4 / 6.27\right)$ with those of methyl-penicinoline $(2)^{6)}$ and penicinoline (3), ${ }^{7)}$ and further confirmed by the ${ }^{1} \mathrm{H}-{ }^{1} \mathrm{H}$ COSY correlations ( $\left.\mathrm{H}-2^{\prime} / \mathrm{H}-3^{\prime} / \mathrm{H}-4^{\prime}\right)$ and the HMBC correlations from H-2', H-3' and $\mathrm{H}-4^{\prime}$ to $\mathrm{C}-5^{\prime}$. The pyrrol ring linked to the quinolinone nucleus was determined by connecting $\mathrm{C}-2$ to $\mathrm{C}-5^{\prime}$ by the HMBC correlations from $\mathrm{H}-3$ to $\mathrm{C}-5^{\prime}$, and from $\mathrm{H}-3^{\prime}$ to $\mathrm{C}-2$, and named as penicinoline E.

The cytotoxicities of all four compounds (1-4) were evaluated in vitro against the HepG2, P388 and HL-60 cell lines using the sulforhodanine B $(\mathrm{SRB})^{9)}$ or 3-(4,5-dimethylthiazol2-yl)-2,5-diphenyl- $2 H$-tetrazoliumbromide (MTT) ${ }^{10)}$ methods. Only compounds $\mathbf{2}$ and $\mathbf{3}$ exhibited moderate cytotoxicities against the HepG2 cell line with the $\mathrm{IC}_{50}$ values of 11.3 and $13.2 \mu \mathrm{M}$, respectively.

Penicinolines is a kind of unusual pyrrolyl 4-quinolinone alkaloids biosynthesised from ornithine and tryptophan, ${ }^{7)}$

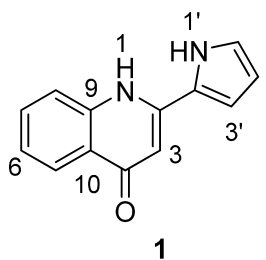

1<smiles>[R]OC(=O)c1c(-c2ccc[nH]2)[nH]c2ccccc2c1=O</smiles>

$3 \mathrm{R}=\mathrm{H}$

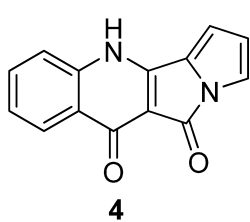

4

Fig. 1. Compounds 1-4 Isolated from Penicillium sp. ghq208 


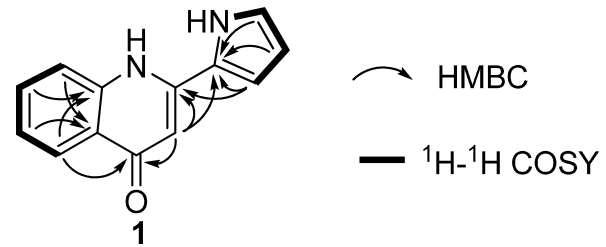

Fig. 2. Selected ${ }^{1} \mathrm{H}-{ }^{1} \mathrm{H}$ COSY and HMBC Correlations of Compound $\mathbf{1}$

which is rare in nature. As far as our knowledge, totally three natural-occurring examples were isolated from several fungi stains such as Auxarthron reticulatum, ${ }^{6)}$ Penicillium sp., ${ }^{7}$ Penicillium sp., ${ }^{8}$ and one synthetical example. ${ }^{7)}$ There has been much recent interest arising from its biological activities, penicinoline (3) showed potent in vitro cytotoxicity toward 95-D and HepG2 cell lines with $\mathrm{IC}_{50}$ values of 0.57 and $6.5 \mu \mathrm{g} /$ $\mathrm{mL}$, respectively, and strong insecticidal activity against $A$. gossypii, ${ }^{7}$ quinolactacide (4) showed excellent insecticidal activity against Myzus persicae, ${ }^{8)}$ and the synthetical example penicinotam showed strong insecticidal activity against $A$. gossypii and $P$. xylostella. ${ }^{7}$ These four penicinolines (1-4) were evaluated in vitro against three tumor cell lines, interestingly, we found that the substitution of carboxyl group at C-3 is an essential for the cytotoxicities of this kind unusual pyrrolyl 4-quinolinone alkaloids. This result indicated that the carboxyl group at C-3 in penicinolines showed be retained in further synthetical investigation.

\section{Experimental}

General Experimental Procedures IR spectra were taken on a NICOLET NEXUS 470 spectrophotometer (Beckman Coulter Inc., Brea, CA, U.S.A.) in KBr disks. The melting point were obtained on a Tianfen Melting Point RY-1 (Tianjin Tianfen Corporation, Tianjin, China). ${ }^{1} \mathrm{H}-,{ }^{13} \mathrm{C}-\mathrm{NMR}$ and distortionless enhancement by polarization transfer (DEPT) spectra and 2D-NMR were recorded on a JEOL JNM-ECP 600 spectrometer (JEOL Ltd., Tokyo, Japan) using tetramethylsilane (TMS) as internal tandard and chemical shifts were recorded as $\delta$ values. ESI-MS was measured on a Q-TOF ULTIMA GLOBAL GAA076 LC mass spectrometer (Waters
Corporation, Milford, MA, U.S.A.). Semi-prepartive HPLC was performed using an ODS column (YMC-pak ODS-A (YMC Co., Ltd., Kyoto, Japan), $10 \times 250 \mathrm{~mm}, 5 \mu \mathrm{m}, 4 \mathrm{~mL} / \mathrm{min}$ ).

Fungal Material The fungal strain Penicillium sp. ghq208 was isolated from the sediments collected in Jiaozhou Bay of China. The voucher specimen is deposited in our laboratory at $-20^{\circ} \mathrm{C}$. Working stocks were prepared on potato dextrose agar slants stored at $4^{\circ} \mathrm{C}$.

Fermentation, Extraction and Isolation Spores were directly inoculated into $1000 \mathrm{~mL}$ Erlenmeyer flasks containing $300 \mathrm{~mL}$ fermentation media (mannitol $20 \mathrm{~g}$, maltose $20 \mathrm{~g}$, glucose $10 \mathrm{~g}$, monosodium glutamate $10 \mathrm{~g}, \mathrm{KH}_{2} \mathrm{PO}_{4} 0.5 \mathrm{~g}$, $\mathrm{MgSO}_{4} \cdot 7 \mathrm{H}_{2} \mathrm{O} 0.3 \mathrm{~g}$, yeast extract $3 \mathrm{~g}$, and corn steep liquor $1 \mathrm{~g}$, dissolved in $1 \mathrm{~L}$ sea water, $\mathrm{pH}$ 6.5). The fungus was grown under static conditions at $28^{\circ} \mathrm{C}$. After $30 \mathrm{~d}$ of cultivation, $40 \mathrm{~L}$ of whole broth was filtered through cheesecloth to separate the broth supernatant, which was extracted with ethyl acetate, and concentrated under reduced pressure to give a crude extract $(6.3 \mathrm{~g})$.

The crude extract $(6.3 \mathrm{~g})$ was fractionated on a C-18 ODS column using a step gradient elution of $\mathrm{MeOH}-\mathrm{H}_{2} \mathrm{O}$ and was separated into 4 subfractions (Fr. 1-Fr. 4). Fraction 2 was further purified by semipreparative HPLC $\left(50: 50 \mathrm{MeOH}-\mathrm{H}_{2} \mathrm{O}\right.$, $4 \mathrm{~mL} / \mathrm{min})$ to give compounds 1 (13 $\left.\mathrm{mg}, t_{\mathrm{R}}=9.8 \mathrm{~min}\right)$, and 2 $\left(15 \mathrm{mg}, t_{\mathrm{R}}=12.0 \mathrm{~min}\right)$. Compounds $3\left(19.3 \mathrm{mg}, t_{\mathrm{R}}=7.8 \mathrm{~min}\right)$, and $4\left(23.5 \mathrm{mg}, t_{\mathrm{R}}=8.7 \mathrm{~min}\right)$ were obtained from Fr. 3, which was also purified by semi-preparative $\mathrm{HPLC}\left(60: 40 \mathrm{MeOH}-\mathrm{H}_{2} \mathrm{O}-\right.$ TFA, $4 \mathrm{~mL} / \mathrm{min})$.

Penicinoline E (1): Pale yellow powder, $\mathrm{mp}{ }^{\circ} \mathrm{C}$ : $358-360$, UV (HPLC, mobile phase) $\lambda_{\max } \mathrm{nm}: 207,271,353$, IR (KBr) $\mathrm{cm}^{-1}: 3412,1659,1564,1465,1297,1144,828,{ }^{1} \mathrm{H}-\mathrm{NMR}$ $\left(\mathrm{DMSO}-d_{6}, 600 \mathrm{MHz}\right)$ and ${ }^{13} \mathrm{C}-\mathrm{NMR}$ (DMSO- $d_{6}, 150 \mathrm{MHz}$ ), see Table 1, HR-ESI-MS m/z: $211.0863[\mathrm{M}+\mathrm{H}]^{+}$(Calcd for $\mathrm{C}_{13} \mathrm{H}_{11} \mathrm{~N}_{2} \mathrm{O}$ : 211.0866).

In Vitro Cytotoxicity Assays In the MTT assay, cell lines were grown in RPMI-1640 supplemented with $10 \%$ fetal bovine serum (FBS) under a humidified atmosphere of $5 \% \mathrm{CO}_{2}$ and $95 \%$ air at $37^{\circ} \mathrm{C}$. Cell suspensions, $200 \mu \mathrm{L}$, at a density of $5 \times 10^{4} \mathrm{cell} / \mathrm{mL}$ were plated in 96 well microtiter plates and incubated for $24 \mathrm{~h}$. Then, $2 \mu \mathrm{L}$ of the test solutions (in $\mathrm{MeOH}$ ) were added to each well and further incubated for $72 \mathrm{~h}$. Then,

Table 1. ${ }^{1} \mathrm{H}$ - and ${ }^{13} \mathrm{C}-\mathrm{NMR}$ Data $(\delta$ in ppm, $J$ in $\mathrm{Hz})$ of $\mathbf{1}$ in DMSO- $d_{6}$

\begin{tabular}{|c|c|c|c|c|}
\hline No. & ${ }^{13} \mathrm{C}^{b)}$ & ${ }^{1} \mathrm{H}^{a)}$ & COSY & HMBC \\
\hline 1 & & $11.81(\mathrm{~s})$ & & \\
\hline 2 & 143.3 & & & \\
\hline 3 & 103.1 & $6.51(\mathrm{~s})$ & & $2,4,2^{\prime}$ \\
\hline 4 & 177.4 & & & \\
\hline 5 & 125.1 & $8.04(\mathrm{dd}, 7.7,1.1)$ & 6 & 4,9 \\
\hline 6 & 123.3 & $7.27(\mathrm{ddd}, 7.7,7.7,1.1)$ & 5,7 & 10 \\
\hline 7 & 132.1 & $7.61(\mathrm{ddd}, 7.7,7.7,1.1)$ & 6,8 & 9 \\
\hline 8 & 118.8 & $7.72(\mathrm{dd}, 7.7,1.1)$ & 7 & 10 \\
\hline 9 & 141.2 & & & \\
\hline 10 & 125.4 & & & \\
\hline $1^{\prime}$ & & 11.33 (brs) & $5^{\prime}$ & \\
\hline $2^{\prime}$ & 125.3 & & & \\
\hline $3^{\prime}$ & 123.5 & $7.08(\mathrm{~m})$ & $4^{\prime}$ & $2,2^{\prime}$ \\
\hline $4^{\prime}$ & 111.0 & $7.05(\mathrm{~m})$ & $3^{\prime}, 5^{\prime}$ & $2^{\prime}$ \\
\hline $5^{\prime}$ & 110.4 & $6.27(\mathrm{~m})$ & $1^{\prime}, 4^{\prime}$ & $2^{\prime}$ \\
\hline
\end{tabular}

a) Spectra measured at $400 \mathrm{MHz}$ at $25^{\circ} \mathrm{C}$. b) Spectra measured at $100 \mathrm{MHz}$ at $25^{\circ} \mathrm{C}$. 
$20 \mu \mathrm{L}$ of the MTT solution $(5 \mathrm{mg} / \mathrm{mL}$ in IPMI- 1640 medium) was added to each well and incubated for $4 \mathrm{~h}$. Old medium containing MTT $(150 \mu \mathrm{L})$ was then gently replaced by DMSO and pipetted to dissolve any formazan crystals formed. Absorbance was then determined on a SPECTRA MAX PLUS plate reader (Molecular Devices, Sunnyvale, CA, U.S.A.) at $540 \mathrm{~nm}$.

In the SRB assay, $200 \mu \mathrm{L}$ of the cell suspensions were plated in 96 cell plates at a density of $2 \times 10^{5}$ cell $/ \mathrm{mL}$. Then $2 \mu \mathrm{L}$ of the test solutions (in $\mathrm{MeOH}$ ) was added to each well, and the culture was further incubated for $24 \mathrm{~h}$. The cells were fixed with $12 \%$ trichloroacetic acid, and the cell layer was strained with $0.4 \%$ SRB. The absorbance of SRB solution was measured at $515 \mathrm{~nm}$. Dose response curves were generated, and the $\mathrm{IC}_{50}$ values, the concentration of compound required to inhibit cell proliferation by $50 \%$, were caculated from the linear portion of log dose response curves.

Acknowledgments This work was financially supported by National Natural Science Fundation of China (Nos. 30973627 and 41176120), Promotive research fund for excellent young and middle-aged scientisits of Shandong Province (BS2010HZ027), the Public Projects of State Oceanic Administration (No. 2010418022-3), and the Program for Changjiang
Scholars and Innovative Research Team in University (No. IRT0944).

\section{References}

1) Blunt J. W., Copp B. R., Keyzers R. A., Munro M. H. G., Prinsep M. R., Nat. Prod. Rep., 29, 144-222 (2012).

2) Khadem S., Marles R. J., Molecules, 17, 191-206 (2012).

3) Du L., Ai J., Li D. H., Zhu T. J., Wang Y., Knauer M., Bruhn T., Liu H. B., Geng M. Y., Gu Q. Q., Bringmann G., Chemistry, 17, 1319-1326 (2011)

4) Cai S. X., Sun S. W., Zhou H. N., Kong X. L., Zhu T., Li D. H., Gu Q. Q., J. Nat. Prod., 74, 1106-1110 (2011).

5) Du L., Liu H. C., Fu W., Li D. H., Pan Q. M., Zhu T. J., Geng M. Y., Gu Q. Q., J. Med. Chem., 54, 5796-5810 (2011).

6) Elsebai M. F., Rempel V., Schnakenburg G., Kehraus S., Muller C. E., Konig G. M., ACS Med. Chem. Lett., 2, 866-869 (2011).

7) Shao C. L., Wang C. Y., Gu Y. C., Wei M. Y., Pan J. H., Deng D. S., She Z. G., Lin Y. C., Bioorg. Med. Chem. Lett., 20, 3284-3286 (2010).

8) Abe M., Imai T., Ishii N., Usui M., Okuda T., Oki T., Biosci. Biotechnol. Biochem., 69, 1202-1205 (2005).

9) Skehan P., Storeng R., Scudiero D., Monks A., McMahon J., Vistica D., Warren J. T., Bokesch H., Kenney S., Boyd M. R., J. Natl. Cancer Inst., 82, 1107-1112 (1990).

10) Mosmann T. J., J. Immunol. Methods, 65, 55-63 (1983). 